\title{
LAND REFORMS IN AN INDIAN STATE: LESSONS FROM THE EXPERIENCES OF IMPLEMENTATION
}

\author{
Prabhat Kumar Datta ${ }^{1}$, Panchali Sen ${ }^{2}$ \\ ${ }^{1}$ Institute of Development Studies Kolkata, Bidhannagar, West Bengal 700064, India. \\ ${ }^{2}$ Department of Political Science, St. Xaviers College, Kolkata, West Bengal 700016, India. \\ *Corresponding author: dattaprabhat@,gmail.com
}

Citation:Datta, P.H., Sen, P., 2018. Land reforms in an Indian State: Lesson from the experiences of implementation. J. Asian Rur. Stud. 2(1): 1-15

\begin{abstract}
Until the shift of developmental policy in India in 1990s the state used to play an instrumental role India's development. By the time India attained independence it was widely regarded that semi feudal landlordism was the main obstacle in the way of national economic regeneration. In this paper an attempt has been to capture the processes of land reforms in India's West Bengal under the Left Front rule and to critically review impact of this programme on village society. This paper also seeks to identify reasons with the help of empirical studies why it has not been possible for the Left Front Government to achieve the declared objectives of the programme. Major transformations in economic, social and political fields during the first two decades of the Left Front rule characterized by the successful implementation of land reform programmes but failed to produce sustained benefits to the poor beneficiaries of land reforms. The panchayat institutions were unsuccessful in making the poor realize that the existing social situation was not conducive for meeting their basic needs. The concluding part of the paper tries to bring together the lessons that the other countries or states in a federal system can learn from the experiences of implementation of land reforms programme in West Bengal.
\end{abstract}

Keywords: Zamindari system; panchayats; left front government; bargadar; land redistribution; gram sansads

\section{Introduction}

Land reforms can be understood in both broad and narrow senses. The early literature on the subject defines land reforms to include all changes in the agrarian structure including credit, market etc. Recent and more widely accepted definition takes a narrow view and includes two things namely, redistribution of land in favor of the landless and small cultivators and tenancy reforms as essential elements of land reforms (Warriner, 1969). In the entire process of land reforms -from initiation to completion the role of the state is decisive. To borrow the words of Kenneth H. Parsons (1960) "in a very deep sense, land tenure problems are power problems, problems of disparity in economic, social and political power."

A close examination of the experiences of implementation in a number of Latin American countries tends to demonstrate that to be effective land reforms require not only government sponsorship but also compulsion. The pre-requisite of successful implementation of land reform is what can be called governmental will because land reform is not a palliative, but a major surgery as it brings about drastic changes (Galbraith, 1951) 
Land reforms involve multidimensional changes in the socio-economic and political spheres more particularly in the developing countries like India where agriculture continues to be the mainstay of the economy. Land reform policy has thus economic, social and political dimensions. Historically speaking, the economic dimension of land reforms involved the ownership of land by a small group that did not actually cultivate but exploited the actual tillers who were the tenants and agricultural laborers. On the other hand, because of inadequacy of returns and absence of surplus with the tenants, they could not undertake improvements on land. The landlords having no personal interest in the lands they owned also did not take interest in investing on land improvement. As a result, land productivity went on declining. This was the dynamics of underdeveloped agriculture. As far as the sociological dimension is concerned in the Indian context, traditionally, the upper castes in India owned land and the lower castes were the tenants/agricultural labourers. Coming to the political dimension, it may be observed that, historically, owners of land have been supporters of the governments in power (Thimmaiah, 2001). This was much more evident during British rule in India. Because of the numerical minority position of the former zamindars and the later landlords and their economic stranglehold over the tenants, they depended on the government for their protection, (thus promoting their own self-interest). At the same time, the government depended upon them for its own survival so long as tenants, though large in number, did not organise themselves against the exploitative political and social systems. Significantly, this has been the experience of almost all countries that faced agrarian problems.

The British rule in India introduced permanent land revenue system which, over time, became widely known as zamindari system. Under this system of land settlement, those who agreed to pay a fixed sum of land revenue regularly to the British government were made the owners of demarcated lands. They, in turn, collected whatever land revenue they wanted from the actual tillers that were their tenants. There was also a practice of sub-letting, which involved middle-level landlords in between the zamindars and the tenants. The zamindari system created one of the worst exploitative land relations between India and strengthened the feudal socio-economic system.

It is fairly simple to divide the unfolding of land policy in India after independence into four periods (Vijay, 2012). The first might be called 'the long 1950s' from independence to the border clashes with China in 1962 when so much of the independence dream seemed to be going wrong. There was a lot of legislations and some notable changes, though none attempting to transfer 'land to the tiller'. The second period marks a time when the food shortages of the mid-1960s led governments to turn their attention to agricultural production and to make the 'green revolution' happen. Simultaneously, peasant insurgency, driven by local conditions and inspired by the Chinese revolution, led to the oft-quoted remark of an important cabinet minister, Y. B. Chavan that there was a danger that the green revolution could become red. The third period represented a response to those conditions and a reflection of Mrs Indira Gandhi's 'socialist' phase. A meeting of Chief Ministers in 1972, in the glow of the successful Bangladesh War, the 1971 election victory and Naxalite insurgencies, generated a wave of legislation addressing inequity in the countryside. The attempts to end bonded labor during the 'emergency' were part of such measures, though they were rarely implemented with persistence. The fourth period begins in the early 1980 s with 
Mrs Gandhi's return to power, the rise of a post-freedom struggle middle class, embodied in Rajiv Gandhi, and a growing belief within that class that the 'socialist experiment' (or 'Nehruvian experiment') had failed The First Five Year Plan (1951-56) observed that increase in agricultural production should be given high priority. It emphasized on tenancy reforms in terms of imposing ceiling on land holdings and restricting the right of land owners to resume lands. It advised that the panchayats should play an important role in dealing with problems relating to tenancy. The Second Five Year Plan argued the case for land reforms in order to remove such impediments to agricultural production as arise from the character of the agrarian structure and to create conditions for evolving, as early as possible, an agrarian economy with high levels of efficiency and productivity

Land reform legislation in India consisted of four main categories: abolition of intermediaries who were rent collectors under the pre-Independence land revenue system; tenancy regulation that attempts to improve the contractual terms faced by tenants, including crop shares and security of tenure; a ceiling on landholdings with a view to redistributing surplus land to the landless; and finally, attempts to consolidate disparate landholdings (Besley, 2000).

After independence the various states went ahead with the abolition of zamindari and talukdari estates i.e estates under landlords and those under intermediary tax- farmers, but reforms, as Lieten says, which benefit landless population and the lowest rank of tenants were not undertaken anywhere until the late 1950s. Some states, however, took a series of steps in 1970s to involve rural peasants in the 'green revolution' and to improve employment and wage conditions for the landless agricultural laborers (Lieten,1996) Kerala under the rule of the communists was the first Indian state to take up the issue of land reforms and West Bengal under the rule of the Left Front in 1977 was the second state to follow Kerala by laying emphasis on land reform as a core of rural development. Incidentally, the earlier two short spells of non-Congress United Front governments with the leftists having considerable importance in the state in late 1960s had tried to unleash a new process of land reforms but failed due to a number of reasons.

Based on the above background, this paper would explain the approach of the Left Front Government (LFG) in West Bengal to land reform with a view to addressing the pressing issue of agricultural stagnation in 1970s; Capture the processes of implementation of land reform programmes including the role of the panchaysts; and critically analyse various kinds of impact of land reform on rural West Bengal with a view to assessing the effectiveness state intervention in the domain of land reforms.

\section{Discussions}

\subsection{The Left Front Government in West Bengal}

West Bengal had from 1977-2910 the longest elected leftist regime in world history spanning over more than three decades. One British scholar observes, "Since 1977 the Communists have governed population larger than that of Britain or France" (Mallick, 1993). It was a coalition of 10 leftist parties led by Communist Party of India (Marxist) (CPI (M) and all of them were Marxists. It has been described by some as the Marxist government with a difference (Datta, 1988). However, it was a pre-election coalition based on a common minimum programme which emphasized, inter alia, land reform for 
dealing with agricultural stagnation in the state and as a core of rural development, democratic decentralization as a part of the process of land reforms, pro-poor governance as the ideological commitment of the LF regime

It may be recalled that West Bengal has a strong tradition of leftism connected with rise of the new middle class (Franda, 1971). During the days of the freedom movement revolutionary nationalist organizations and left wing peasant unions had emerged in the Bengal and the leftists were instrumental in the spread of the Tebhaga movement after the 1940s. It was movement of the sharecroppers for introduction of better tenurial conditions in respect of sharing of crops between the owners and the sharecroppers

The imposition of ban on the Communist Party of India (CPI) for organizing strikes in the early 40s forced the leftists to enter into in the electoral politics in 1952. Alongside they continued to carry out their political programme to organize people for struggles. West Bengal witnessed in late 1960s and early 1970s series of movements, demonstrations against price rise, industrial recession, shrinking of employment opportunities and continuing food crisis organized by the leftists. All these paved the road for the left parties in West Bengal to come closer and form electoral fronts.

It was a time when rural economy of West Bengal had been in a very bad shape. Growing unemployment, declining real wages and declining food production put the state in a quandary. The Left Front was voted to power against the backdrop of increasing economic distress of the common people, 'misrule' of the Congress which replaced the United Front in 1970s and a new progressive programme of the leftists in the form of common minimum programme for improving the living conditions and quality of life of the down-and out and pro-poor governance with participation of the governed.

\subsubsection{The Tasks of the Left Front Government on the Rural Front}

Rural Bengal received considerable attention of the LFG ever since it was installed in 1977 primarily for two reasons. First, the data of the Assembly elections held in 1977 showed that its support base of the left parties in the rural areas was weaker than that in urban areas. The L.F. secured 49.1 per cent votes in urban districts like Kolkata, Howrah, 24-Parganas, Hooghly but in rural districts like Murshidabad, Midnapore, Coochbehar, Jalpaiguri, Bankura, Purulia, Birbhum, West Dinajpur, Malda it was 41.3 per cent. Second, its common minimum programme had special focus on rural Bengal.

Broadly speaking, the LFG had two tasks on the rural front:

- Regeneration of the stagnant rural economy primarily through land reforms and other state interventions. It became urgently imperative because agricultural sector growth in West Bengal at that time was $11.9 \%$ while the national average was $32.3 \%$

- Democratization of the rural governing processes through panchayati raj institutions holding elections to panchayat bodies. The last general elections to these bodies were held only in 1957 and village democratic institutions were virtually paralysed primarily due to lack of political and bureaucratic support.

Atul Kohli (1989) has argued that the L.F.G. had two options to ensure political entrenchment in rural Bengal, namely, rapid expansion of the party and restructuring of local government The L.F.G. opted for the latter. The LF leaders might have felt that the rapid expansion of the party would destroy the party as the well-knit and disciplined 
organisation. Second, it was intended to accomplish its political goals by building its power base primarily on the lower middle class and lower classes. Given the inherent disadvantages of the first option, LFG might have opted for the second.

The LFG was aware of the constitutional restrictions on its resorting to independent administrative path in tune with its ideological and political commitment. It was argued by the government that in the existing framework of the center-state relations, none of the state governments in general and Left Front Governments in particular can exercise their option in the choice of any developmental strategy other than the one imposed by the center It was pointed out that as there was no scope of adopting an alternative strategy, the LFG resorted to an alternative approach. Land reform was cited as one of the most important characteristic features of this new approach. It may recall that the LFG claimed that land reform was inseparable from democratic decentralization and the two together were the two legs of the rural development programme of the LFG in the state (Mishra,1991)

This alternative tactical approach, as the Minister-in-charge of Panchayats and Rural Development, Government of West Bengal termed it, had three objectives' The first objective was to involve the entire people in the processes of development through democratic decentralization of power in both rural urban areas. It was decided that panchayats would act as the instruments of planning and implementation of all rural development programmes. The second objective was to bring about a change in the corelation of class forces in the countryside in favour of the poor, working people by involving them in an organized manner in the processes of development. It was contended that this could be achieved through land reforms with emphasis on redistribution of land and speedy registration of names of sharecroppers to be followed by providing the beneficiaries with non-land input support through panchayats. The third objective was to extend maximum possible relief to the poor increasingly forced to bear the burden of the economic crisis in the country It was clearly mentioned that utmost restraint would be taken to see that the people do not suffer from any illusion that their basic needs would not be fulfilled without a radical structural change in the existing relations of productions.

\subsubsection{New Crop of Rural Leadership}

Immediately after coming to power the LFG started taking steps for holding elections to the moribund panchayati raj institutions. The first elections to panchayat institutions under the LFG were held in June 1978. The most striking thing in this election was open participation of all the political parties for the first time in the history of panchayat elections in India The LF fought the elections with a slogan which emphasized on breaking the hold of the vested interests in the villages -bastu Ghuguder Bansha Bhago the slogan indicated the agenda of the government in rural West Bengal as well (Datta, 2003).

The elections to the PRIs under the LF rule brought into being a completely new crop of rural leadership in terms of class composition of the elected leaders. Kohli commented that it was unprecedented in the history of panchayat elections in the country as well. To quote, "the new panchayats of West Bengal represent a break from the past political patterns in rural India. The panchayats in West Bengal or in most parts of India have seldom been so free of domination by landlords or rich peasants" (Kohli, 
1989, Datta, 1999). A large number of macro and micro studies suggested that panchayats were free from the domination of the big landlords. Several studies suggested that the Panchayats at the village level were controlled mainly by the middle farmers who already had significant resources under their control with a large percentage being teachers and other professionals

This trend continued unabated as we find from a comparative study. Comparing 1978-83 with 1988-93 gram panchayats. Sarkar (2008) says that representation of bargadars (sharecroppers) has increased from 1.8 per cent, that of landless labour from 4.8 per cent to 16.8 per cent and the representation of the cultivators with landholding below 3 acres along with landless increased from 21.8 per cent to 30.17 per cent. All these have brought about a change in the co-relation of class forces in the countryside and "churning of the submerged humanity". The new leadership played a key role in the implementation of land reform programmes. The transformational potential of the panchayats has been documented by Gent (1993) in the book The State and the Poor who state that panchayats as an institutional system that allows for the possibility that subaltern groups may exercise as their agency to accumulate political and economic resources and reduce social inequities.

The three-tiered panchayats were made the primary instruments of implementation of all rural development programmes in West Bengal. There were two kinds of rural development programmes - centrally sponsored general programmes namely, improved health conditions, drinking water supply, school environment, literacy classes, all weather roads etc. and state-sponsored class-centred programmes such as land reforms, increasing agricultural wages. The government laid stress on three aspects of land reforms, namely, quick recording of names of sharecroppers, redistribution of surplus lands among the landless and extension of support to the beneficiaries through panchayats including arrangement of institutional credit cover to them.

\subsection{Land Reforms: Different Components}

The core of rural development policy of the LFG was land reforms as emphasized by the Chief Minister in his letter to the Prime Minister (Basu, 1986). Benoy Chowdhury who was the Minister -in -charge of Land Reforms in West Bengal felt that the primary objective of land reform in West Bengal was removal of the structural anomalies in the rural society by bringing about a publicly controlled change in the land ownership and to correct pattern of the land tenure system so that the intermediary interests in land are eliminated and the security of tenure of the actual tillers of the soil was ensured (Lieten, 1996). Since 1977 there had been three intervention in the domain of land reforms, namely, land distribution and tenancy reforms, increasing financial allocation to agrarian inputs and the new local power structure of the panchayats. The Economic Review (1992-93) published by the Government of West Bengal explains the structural change in agricultural production as a strategy which is 'not only to redress the inequitable distribution of land holding but also to rely on small and marginal farmers as well beneficiaries of land reforms to provide the growth impetus to agricultural production---it is this strategy that has brought the poor in the rural areas into production fold while neutralizing the pernicious hold of the feudal elements over the rural economy. 


\subsubsection{Tenancy Reform}

Share cropping is an old institution in West Bengal and sharecroppers (bargadars) play a very significant role in the rural economy. By definition a bargadar means a person who cultivates the land of another person on condition of delivery of a specified share of the produce. A bargadar has no right over lands. He has the right to cultivate lands. In undivided Bengal there were different patterns of sharing depending on the local practice. The most common division was 50:50 when inputs were supplied by the bargadar During the days of the British rule the bargadars cultivated lands on their own in an adverse production relations regime in the second half of the 1940s Bengal witnessed unprecedented agitations of the bargadars commonly known as the Tebhaga movement. The state responded to the movement by fixing the share. The West Bengal Bargadars Act fixed the sharing pattern for the first time. It is laid down that a bargadar or the owner of the land who supplies the seeds, would at the first place be entitled to a quantity of the produce equivalent to the quantity of seeds supplied. One third of the remaining produce would go to the bargadar and another one third to the owner. The balance would be shared between them in proportion to the cost of cultivation provided by each.

The West Bengal Land Reforms Act introduced a major changes in the sharing pattern. It stipulated that if the input was provided by the owner sharing between bargadar and owner shall be 60:40. Later on, the owner's share was decreased to 25 per cent from 40 per cent and the share of the bargadar was increased from 60 to 75 per cent. Significantly neither the colonial Bengal Tenancy Act nor the post-colonial West Bengal Estates Acquisition Act during the Congress regime made any provisions in the substantive part of the act for recording the names of the bargadars in the revenue records. It is only in the subordinate legislation that such provisions were made. And again, till 1950 no Act or law was enacted incorporating their rights and liabilities.

The land reforms programme was implemented by the bureaucracy exclusively and the progress was very unsatisfactory. The LFG decided to supplement the traditional mode of agrarian reform by establishing a linkage among the bureaucracy, peasants and the panchayat bodies. It was clearly mentioned by a peasant leader of the CPI (M), Hare Krishna Konar who was in charge of the Land Reform Department in the first United Front regime stated that "although there are some honest officers in the administration, bureaucracy is very powerful impediment of land reform programme" (Konar, 1967). He believed that "history teaches us that land reforms cannot be implemented merely by official efforts and by seeking advice of the vested interests in the countryside. To ensure effective implementation of the land reforms, active participation of the millions of the landless and land-poor peasants who are the actual beneficiaries of the programme, is considered a must. Without such active participation and cooperation of the organized movements of the landless and land -poor peasants, the conspiracy and machinations of the big landlords and zamindars to frustrate land reforms cannot be encountered (Konar 1967).

The tenancy reform programme under the Left Front Regime was implemented through the following two innovative strategies:

a) The LFG took steps to bring about some legal changes supportive of sharecroppers' claims. Among the changes in the land laws the onus of proving that he does not have sharecropping rights, was placed on the landowners. The 
eviction of sharecroppers for the ostensible purpose of self- cultivation was made more difficult by defining self- cultivation more rigorously to mean participation by the land-owners and/or the person's family as manual labour related to cultivation.

b) The LFG utilized the mobilization of the rural poor for the implementation of land reform through the involvement of party based panchayats and party-led peasant organizations. The strategy was to rely on group action on the part of the beneficiaries to enable them to overcome the fear psychosis by creating a mutual support system.

It was decided that the old practice of registration of names of the bargadars usually in the houses of the land owners would be replaced by a new mode of what was popularly called evening camps. The entire exercise was started after holding interactive meetings of the bureaucracy with prospective beneficiaries of land reform. It was intended to create an atmosphere of relationship of respect and concern for each other between two sets of participants in the process. These conscientization camps helped the bureaucracy to think afresh of their role as change agents. "It sets in a process of change of mind at least among a few functionaries at the cutting edge of administration" (Bandyopadhayay, 1978).

Actual meetings for the registration of names of the sharecroppers were held in the villages in the evenings which were attended by the land reforms officials, members and heads of panchayats, the sharecroppers, and land owners. While doing a study on the processes of implementation the author had noticed that the evening camp started with an address by the panchayat chief. He promised wide ranging support to the beneficiaries by promising to be with them to protect their interest against the onslaught of the land owners. While interviewing the sharecroppers it was gathered that this was preceded by a meeting in every locality organized under the auspices of the Krishak Samiti, the peasant wing of the CPI(M) (Datta, 1988). This meeting enthused the bargadars to come forward for registration of their names as bargadars

However, after such meetings a tentative list was prepared. The landowners were allowed objections which were also heard and verified in public. This was followed by the issue of certificates. In these meetings petitions were received from the intending bargadars. Inquiries were held by the revenue officials next day or the day after. In course of three days certificates were issued to the bargadars. They were furnished with a copy of the record of rights as soon their names were recorded. This document enabled them to take loans from the banks and assured them their right to cultivate the lands without any difficulty. Earlier they had to seek permission from the land owners for cultivating the lands at the end of the year.

The recorded sharecroppers were not afraid of confronting their landowners for getting their dues. The study by this author had shown that in case of disputes regarding the share of crops between them and their landowners they did not surrender to the former. They preferred to take the matter up with the panchayats and peasant organizations ( Datta, 1988). While panchayats provided them support from within the political sub- system, the peasant organizations provided them support from outside. Thus they were assured of support from within and without. The panchayats and peasant organizations played the most effective role in implementing these programmes. In fact, "West Bengal", as Baruah (1990) argues, "provides one of the rare instances of land 
reform programmes initiated by radical rural political mobilization with significant participation by the agrarian underclass." (Baruah, 1990) and significantly, as Ruud (1999) observes, the reforms were "effectuated through the use of the mobilized supporters more than the administrative machinery" It was claimed that with the association of village panchayats the average rate of recording increased by about 300 per cent.

\subsubsection{Land Redistribution}

It is preceded by the acquisition of ceiling surplus land in terms of the West Bengal Estates Acquisition Act. Land ceiling began to gather attention since the middle of the 1950s. By the end of the decade a considerable area of the land was vested on the basis of the returns filed by the landowners. But many of them took advantage of the legal loopholes and clandestinely retained ceiling surplus lands. A large chunk of lands remained to be distributed.

The dismal record of the then Congress government in this regard caused discontent among the landless peasants. Movements were organized at the instance of the left parties in different districts to put pressure on the government for the redistribution of the lands. During the short spells of the United Front governments vigorous drive was launched with the help of the politicized peasant organizations to detect ceiling surplus lands held in different names (benami) lands. This drives resulted in the detection and vesting of large quantity of lands. This had had brought about a perceptible change in the rural power structure because the poor were organized to resist coercive actions of the landlords. But this drive was very short-lived because these governments had a very stint.

The "red panchayats" as they were popularly called in those days because of their domination by the CPI(M) were involved in the task of carrying out the land redistribution programme. The West Bengal Panchayat Act, 1973 was amended to create a standing committee on land reforms at the level of the lowest tier of the panchayat, Gram Panchayat, to perform this task. It was this committee which, with the help of the Gram Panchayats, prepared the list of persons to whom the vested lands would be redistributed. In this process unofficial involvement of the peasant organizations was quite significant However, the success has been commendable. Of the total agricultural land redistributed through land reforms in India nearly 20 per cent was contributed by West Bengal, although in the total agricultural land in India the state's share is less than 04 per cent. The distribution of lands, even of unviable mini-plots was expected to strengthen bargaining power of the beneficiaries and breaking the feudal bind. And 50 per cent of the beneficiaries came from two marginalized sections of the population known as Scheduled Castes (SC) and Scheduled Tribes (ST).

The two measures together have resulted in a structural situation considerably different from that in most other states in India. These steps have tilted the power balance in rural areas in favor of the small and poor producers and have thus created conditions conducive to the empowerment of the poor. It is interesting to note, as Webster reminds us, that it was not simply political organization of the poor but organization around different types of productive activities such as fish, irrigation, molasses manufacture, around market activities such as fish, milk, bidi, rice, around poverty relief activities such as grain stores, education, club and around social and 
religion activities which facilitated the process of major transformation in Bengal villages. Elsewhere Webster says that the presence or coming together of these three dimensions - local institutional channels, a discourse on poverty, and political organizing practices - created political space in 1980s and 1990s that the poor have gained from. It has led to a process of democratization at the local level that has helped to secure pro-poor development path in this period (Webster, 2000).

\subsubsection{Distribution of Homestead land}

Coupled with two major components land reform programme in West Bengal under the LF regime includes assignment of homestead lands. It is no less important than other two aspects because ownership of homestead land means not only a space to live but also represents access to a new source of potential of nutritious livelihood support as result of house site and kitchen garden cultivation. Aparajita Bakshi (1997) has found in her study of seven villages that SC and ST households were the major beneficiaries. Out of 230 beneficiaries 21 per cent belonged to the SC group, 46 per cent were tribals 24 per cent Muslims and 10 per cent belonged to other caste groups.

\subsubsection{Non-Land Input Support}

In order to make land reforms measures meaningful and useful to the beneficiaries it is essential to support these measures with the provision of non-land inputs, such as irrigation, agricultural implements, manures and fertilizers and infrastructural facilities, particularly credit and marketing. Otherwise, the beneficiaries would be left to the mercy of the market. As a matter of fact in South Asia and Japan where land reforms were successfully carried out, post tenancy reform support to the beneficiaries was considered an integral part of the reform process.

This support has far reaching consequences on the beneficiaries in West Bengal. It instilled in them 'a sense of self-confidence and dignity'. More than 70 per cent respondents for the study done by the present author himself on land reforms reported their ability to cultivate land without any support from the landowners. This support went a long way in freeing the beneficiaries from the clutches of the land owners. The International Labour Organization commented favorably on the government's decisive action for peasants, sharecroppers and agricultural labourers against landlords and big farmers and on the direct communication in a way that instilled confidence in the poor (ILO, 1979).

The small land owners had benefited from land reforms in West Bengal. It is vindicated by the findings of another study done by Vikash Rawal (2001). The study showed that while in other states the net buyers of cultivable land were large land owners and the net sellers of agricultural lands were small landowners, the trend was quite the opposite in West Bengal.The author attributed this difference to the increased purchasing power among the poor in West Bengal facilitated by land distribution, tenancy reforms, higher wage rates and access to credit (Bakshi, 2007). Anil Chakrabarti's study has demonstrated that a good number of bargadars have been able to acquire capital assets like lands out of their own resources, It shows that they have been able to improve their economic conditions (Chakrabarty, 2003). 


\subsection{Impact of Land Reform}

\subsubsection{Economic Impact: Increase in Food Production}

Boyce in his study done in 1987 collected huge data to prove that during the long pre-LFG period food grain production lagged behind population growth by almost one per cent, and that roughly 70 per cent of the population fell short of the officially defined calorie intake. He thought that the sharp production increase after the accession of the LFG to office was striking. The output figures showed that during the Seventh Plan Period (1985-90) West Bengal was ahead of all other states in terms of per capita food grain consumption and in terms of food grain production (Boyce, 1987). While not being clear about how the figures were calculated the Mukerjee-Bandyopadhayay Committee observed that while going around the village they noticed an upsurge of agricultural production. The Committee offered two arguments. First, positive interventions by the state in a variety of ways evidently helped farmers to step up both productivity and production. Second, land reforms have also contributed in the sense that its direct beneficiaries, patta holders and recorded bargadars are motivated to register high production. While explaining the point the committee observes that panchayats have played an important role in this regard because they have acted implementing agencies of both land reform and state interventions (MukherjeeBanerjee' 1993).

There was another remarkable positive impact, namely, reduction in poverty. The World Bank categorized West Bengal as the leader state in poverty reduction in India in 1990s (The World Bank, 2000, Bardhan and Mukherjee, 2004). The proportion of people below poverty line declined from 52.5 percent in 1978 to 27.6 percent in 1988 . In 1978 West Bengal was fifth from bottom in the all-India rankings, with the percentage of population below the poverty line standing at 4.4 percent higher than the national average. By 1991 this figure came down to 2.3 percent below the national average. As a result West Bengal was placed in the seventh from the top.

\subsubsection{Social Impact: Churning of the Submerged}

The successful implementation of land reform programme and other interventions by the state has transformed rural social scene and life. It led to 'the churning of the submerged' The poor peasants have been able raise their voice of protests when required and are no longer a second fiddle to the land owners. Their social status has improved in the sense that they have started receiving treatment as human beings in the society. Their level of literacy has increased resulting in a change in their consciousness about health education etc. The official study showed that there had been a significant increase in the cases of vaccination of the rural poor. They started realizing the importance of sending their children to the schools (SIPRD, 2005).

\subsubsection{Political Impact: Electoral Benefit}

The landless and socially and educationally backward sections constituted a strong base of the Left Front (Bardhan, 2009). They extended their political support to capture panchayats and form state governments for long time. The party based panchayats played key role as instruments of political mobilization in successive panchayat elections The left parties could strengthen their party organizations with support of panchayats as well. The beneficiaries of land reforms continued to be the most solid 
support base of the Left Front as long as they could stand by them. Land reforms at one point of time became 'a squeezed lemon'. The erosion of this support base started after 1990s primarily for three reasons.

First, the local political leaders who were panchayat leaders as well, took for granted that the beneficiaries of land reforms would continue to support them irrespective of their support for them. Second, increasing partisan approach of section of the leaders in the distribution of benefits through panchayats, alienated a section of the poor. The tragic death of the poor tribal people in Amlashol in the tribal dominated backward areas in West Midnapore due to lack of food brought out the partisan role of the panchayats to the fore. There is a view that starvation deaths in Amlashole took place because of the arrogance and partisan decision on the part of the dominant section of the of the party activists who did not allow the panchayats to work and kept it under animated suspension. The villagers were discriminated on the basis of their political allegiance as the field visits by the author indicated. It has been rightly observed by one scholar that "detached from movement and comfortable with munificence of administrative power a section of party's leadership acquired bureaucratic habits of conducting itself, various corrupt and accumulative tendencies thrived, reformist party's organic linkage with the everyday's lives of the masses and communities snapped" (Chakrabarty, 2011). Third, the rise of a new political class with vested interests and high degree of arrogance complicated the situation further as the distance between them and the poor increased considerably.

\section{Conclusion}

Rural West Bengal witnessed major transformations in economic, social and political fields during the first two decades of the Left Front rule characterized by the successful implementation of land reform programmes that benefited the largest chunk of the marginalized sections of the population. Kheya Bag (2011) writes, "Over their first decade the left front reforms appear to have facilitated more egalitarian Green revolution than in most other Indian states ---Panchayats played a key role by distributing central government funds for building infrastructures such as roads and tube well irrigation which also provided off-season jobs. Subsequently total working days for agricultural labourers in West Bengal rose to the highest in India. Within CPM's two terms increased productivity and year round employment led to the rise in real wages. Mean per capita consumption doubled in ten years and rural poverty (head count) dropped from 60 per cent to under 35 per cent in the late 1980s. Party cadres were instrumental in settling payment disputes a key site of local struggle The CPM was thus able to cement its electoral base by mediating between different sectional interests."

But the interventions of the LFG in the agrarian sector failed to produce sustained benefits to the poor beneficiaries of land reforms. Chakrabarty and others has indicated that the performance of the LFG in respect of land reforms was not satisfactory. The government failed to extend necessary support to the bargadars as a result of which some of them lost possession over lands. Although the percentage was not very high around 3 per cent, it is a matter of concern because it happened at a time when the LF was in power and the panchayats were under their control. The study brought out that one fourth of the total number of bargadars suffered from a sense of insecurity of their tenure. It speaks of the failure of the 'red panchayats' to extend necessary support to 
them as promised at the time of registration. The study shows that only an insignificant percentage of the beneficiaries of ceiling -surplus lands (pattadars) has received minikits which is a direct intervention by the Government in the production efforts of the land reform beneficiaries. This explains partly why West Bengal could not sustain its agricultural productivity. This is a clear failure of the left dominated panchayats which were expected to arrange it for them

It needs to be emphasized that the LFG failed to inculcate in the minds of the rural poor the limitations of their agenda and sensitize them of their role in this regard. It is evident from my own study in 1996. ${ }^{36}$ (Datta,1988) Their policy had generated a feeling that the state and the grassroots democratic institutions would take care of everything even if they did not raise their voice to demand their due as and when required. This explains why the meetings and demonstrations organized at the instance of the left parties and their frontal organizations in the villages declined in late 1990s. Their long stint in government and lack of effective opposition might have eaten into the vitals of the left parties. It was strongly felt when liberalization had started off and the poor peasants started experiencing the impact of it in their everyday life without much protest. The left parties failed to mobilize the masses against the onslaught of liberalization even when the subsidies on fertilizer were reduced considerably. This explains why the issues of liberalization did not figure in the discussions of the meetings of the Gram Sansads which used to meet twice a year to discuss the issues of rural development and related matters ${ }^{37}$ (Ghatak and Ghatak, 2002). The panchayat institutions were unsuccessful in making the poor realize that the existing social situation was not conducive for meeting their basic needs.

\section{Notes:}

- Zamindari system: It was a system of permanent settlement introduced in India by Lord Cornwallis in 1793 in few provinces namely, Bemgal, Bihar, Orissa and Varanashi. Zamindars were recognized as owners of the lands. Zamindars were given the rights to collect the rent from the peasants.

- $\quad$ Ryotwari System was introduced by Thomas Munro in 1820. In Madras, Bombay, parts of Assam and Coorgh provinces of British India. In Ryotwari System the ownership rights were handed over to the peasants.

The British Government collected taxes directly from the peasants.

- Panchyat system: It is three tiered local self governmental structures in the villages. Most of the members are directly elected by the villages. Unlike in most of the states in India the elections to all these tiers are held along political lines.

- Gram Sabha: It is direct democratic deliberative body for each gram panchayat.

- Gram Sansads: It is the lowest tier of direct democracy where the villagers interact directly with their elected representatives. 


\section{References}

Bag, K., 2011 'Red Bengal's Rise and fall', New Left Review, July-Aug.,

Bakshi, A., 2007. 'Index of Equity' Frontline, April, 20.

Bandyopadhaya, D., 1978. Land Reforms in West Bengal Calcutta: Government of West Bengal.

Bardhan, P., and Mukherjee, D. 2004. Poverty Alleviation Efforts of Panchayats in West Bengal, Economic and Political Weekly, February 28.

Bardhan, P., Sandip M., Mookherjee, D., and Sarkar, A. 2009. 'Local Democracy and Clientalism: Implications for Political Stability in West Bengal', Economic and Political Weekly 28 February.

Baruah, S., 1990. 'The End of the Road in Land Reform, Limits to Redistribution in West Bengal', Development and Change, Vol. 21.

Basu, J., and Gandhi, R., 1985. Anti-Poverty Programmes: The Role of Panchayats. Correspondence between Shri Rajiv Gandhi, P.M. of India and Shri Jyoti Basu, C.M. of West Bengal, Kolkata: Department of Information and Cultural Affairs, Government of West Bengal.

Besley, T. and Burgess, R., 2000: "Land Reform, Poverty Reduction, and Growth: Evidence from India", Quarterly Journal of Economics, Vol. 115, No. 2,

Bipin, C., Mukherjee, M., and Mukherjee, A. 1999. India After Independence :19472000. New Delhi: Penguin Books.

Chakrabarti, A. K., et.al., 2003. Beneficiaries of Land reform: West Bengal Scenario, Kalyani: State Institute of Panchayats and Rural Development, Government of West Bengal.

Chakrabarty, B., 2011. The 2011 'State Assembly Elections in West Bengal: The Left Front Washed -Out' Journal of South Asian Development.

Datta, P. K., 1988. 'Left Front Politics in West Bengal' in Singh Bhawani (ed) Politics, Change and Modernity in Indian States, Jaipur: Print Well Publishers.

Datta, P. K., 1988. Land Reforms Administration in West Bengal, New Delhi: Daya Publishing House.

Datta, P. K., 2003. Panchayats, Rural Development and Local Autonomy: The West Bengal Experience, Dasgupta \& Co., Kolkata.

Echverrri-Gent, J., 1995. The State and the Poor, Vistaar, New Delhi.

Franda, M., 1971. Radical Politics in West Bengal, Massachussets: MIT Press.

Galbraith, J.K., 1951. "Conditions of Economic Change in Underdeveloped Countrie" Journal of Farm Ecnomics, 1951.

Ghatak, M. \& Maitreya, 2002. 'Recent Reforms in the Panchayat System in West Bengal: Towards Greater Participatory Government?' Economic and Political Weekly, January 5

ILO, 1979. Overcoming Rural Underdevelopment. Geneva.

Kohli, A., (1989). The State and Poverty in India: Politics of Reform, New York: Cambridge University Press

Konar, H, 1967. 'Land Reform in West Bengal', Mainstream, July, 29

Konar, H., 1977. Agrarian Problems of India, Kolkata: Agrarian Research Centre, Calcutta,

Lieten, G. K., 1996, Decentralisation, Development and Democracy: Village Discourse in West Bengal, Sage. 
Lieten, G.K., 1996. "Land Reforms at Centre Stage: Evidence on West Bengal", Development and Change, January.

Mallick, R. 1993. Development Policy of a Communist Government, New York: Cambridge University Press.

Mishra, S. K., 1991. An Alternative Approach to Development: Land Reforms and Panchayats, Calcutta: Department of Information and Cultural Affairs, Government of West Bengal.

Mukarji, M.N. and Bandyopadhaya, D., 1993. New Horizons for West Bengal's Panchayats: A Report for the Government of West Bengal, Calcutta: Department of Panchayats, Government of West Bengal.

Report of the Task Force on Agrarian Relations, 1973. New Delhi: Planning Commission

Ruud, S. B., 1999. Sonar Bangla? Agricultural Growth and Agrarian Change in West Bengal and Bangladesh, Sage, London.

Sarkar, A., 2008. The Economy of West Bengal, Economic and Political Weekly, December, 27

State Institute of Panchayats and Rural Development Study. 2005. (unpublished)

The World Bank. 2000. Decentralisation Thematic Team, Washington, DC

Thimmaiah, G., 2001. "New Perspectives on Land Reforms in India", Journal of Social and Economic Development, July-Dec.2001.

Vikas, R., 2001. "Agrarian Reforms and Land Markets: A Study pf Land Transactions in Two Villages in West Bengal 1977-1995" Economic Development and Cultural Changel, Vol 49, No.3.

Warriner, D., 1969. Land Reforms in Principles and Practice. Oxford University Press.

Webster, N., 2000. "Democracy, Development and Institutionalised Participation of the Poor in Poverty Reduction" in Paul Collins (ed.) Applying Public Administration in Development Guideposts to the Future, London: John Willey and Sons Limited. 